\title{
Development of Interest in Reading on the Part of Students and Future Academics
}

\author{
Jana Doležalová * \\ Received: September 15, 2017; received in revised form: November 6, 2017; \\ accepted: November 7, 2017
}

\begin{abstract}
:
Introduction: Interest in reading and reader activities cannot be developed efficiently without deeper knowledge of the effects of relevant factors.

Purpose: The aim of this paper is to provide information on the specifics of the creation of interest in reading in the course of future academics' lives.

Methods: This knowledge was obtained from second-year teacher students in the bachelor program at the University of Hradec Kralove by means of readers' biographies and interviews. After six years, the investigation was repeated. Participants' written records about their development of interest in reading were analysed, open-coded and category coded.

Limitations: The results apply to only a sample of university-educated persons in the field of teaching.

Conclusions: Realized experiences encourage interdisciplinary discourse and cooperation in deepening the knowledge about this topic and its follow-up application in teacher training at universities in all teaching specializations.
\end{abstract}

Key words: interest in reading, reader biography, students, teachers, future academics

\section{Introduction}

For a long time, we have been hearing that children do not read and prefer sitting behind their computers. This fact is unfortunately proved also by the research of experts. Causes of children's lack of interest in books include the time spent behind their computers (for example Trávníček, 2008), insufficient time spent talking about books (Lepilová, 2014), and even a lack of inspiring literary education (Gabal \& Helšusová, 2002; Garbe, 2008, Pazonyi \& Bodonyi, 2013). Children also have many other opportunities of spending their leisure time. Concerns about a loss of interest in reading are justified. A serious danger exists that they will be deprived by the influence of reading both on the development of their personalities and on their relationships withothers. Reading and readership can bring new skills and experiences for creative and thoughtful work with textual information, which is necessary for coping with the actual demands of the information society. Regular readers equipped with these abilities learn more efficiently

\footnotetext{
* Jana Doležalová, Tomas Bata University in Zlín, Faculty of Humanities, Czech Republic; jdolezalova@utb.cz
} 


\section{Acta Educationis Generalis \\ volume 7, 2017, issue 3}

(Anderson, Hielbert, Scot, \& Wilkerson, 1985, as cited in Bell, S., M. \& McCallum, R., S. et al., 2008, p. 245) and use media more competently. ${ }^{1}$

So, there are compelling reasons why it is really important to get to know the factors, structural elements, and dimensions of readership comprehensively and study their development.

Readership is a social and multi-dimensional phenomenon. It represents the structure of readers' interests, customs and habits, preferences and attitudes to reading and literature. It is manifested in the readers' behaviour, for example selection of a book and the cognitive and emotional processes associated with reading - understanding the content, intensity of immersion in a book and interpretation of reading (Trávníček, 2008). It is necessary to get to know this comprehensively so that actions in this area are adequate and efficient.

Interest, as one of the most significant components of this phenomenon, is raised by a number of stimuli, and, on the other hand, it also affects many processes. It facilitates the understanding of the text and takes part in creating a relationship with reading and, retrospectively, strengthens this emotional aspect. ${ }^{2}$ A model of a wider conception of reading with its reflective and interactive dimensions, when discussions about the read books take place (Groeben \& Hurrelmann, 2002, as cited in Garbe, 2008, p. 10), supports the understanding of texts, but also the interest in reading and attitudes towards it.

Readership, and also an interest in reading, is dependent on the social context - on various factors and on special social situations. It is affected by the stimulating effect of the environment, in particular by the family and the school and, further, by peers. Cultural conditions and value systems of the society, which is subjected to many changes as well, have a mediated effect on readership.

Every person processes external effects in his/her specific manner that corresponds with his/her individual dispositions, age specifics and experiences. The permeation of individual and social aspects cannot result in identical states of readership in different individuals, however, it can evince a number of specifics and distinctions. That is why it is necessary to come to realize them and respond to them adequately.

\section{Discourse on the conception of a reader}

A person who reads or likes reading is called a reader in everyday communication. $\mathrm{He} / \mathrm{she}$ is defined according to various criteria in professional discourse, most often, according to the number of books read in a certain period, of time, attitudes towards reading, etc. Very often, just readers as the opposite to non-readers are mentioned. We assume that this cannot correspond with the reality owing to the above-mentioned knowledge. It is stigmatizing and determining for a child reader, since in addition to his/her specific development profile, every child also has distinctive reader's characteristics (Homolová, 2008, p. 52). So, differentiation into more types of readers can be assumed.

\footnotetext{
${ }^{1}$ Proficient readers are also better TV viewers - they remember much more, know how to capture the main thought better (Bonfadelli \& Saxer, 1986, as cited in Garbe, 2008, p. 8).

${ }^{2}$ We usually call reading "reading for enjoyment". It represents reading for joy and pleasure.
} 


\section{Acta Educationis Generalis \\ volume 7, 2017, issue 3}

\section{Discourse on the actual research results}

Research on readership using quantitative methods is, of course, beneficial. However, due to the generalization and concentrating on average results, much information can remain concealed. A method using reader biographies discovers more realistic and detailed knowledge, specifically regarding development. It was confirmed through this method, for example, that reading at all stages of individual development depends on the direct influence by persons, such as family members, teachers, librarians and booksellers, who can give readers individual and competent advice (Garbe, 2008). Other researchers also revealed some critical periods of readership development in the course of readers' socialization, in which primary and secondary initiation dependent on social needs takes part significantly (Graf \& Schön, 1993, as cited in Garbe, 2008). They also gave evidence of social support at higher stages of readership development. There is no research focused on this topic ${ }^{3}$ in our conditions, and that is why we intend to fill this gap.

Readership cannot be presented only by the description of the "traditional" stable reader's characteristics, but rather as a variable structure reflecting the dynamics of the reader's life (Poslední, 2005). The interest in reading can change at various stages of a person's development. We assume that it can also be different in periods due to the changing social and cultural conditions in the society.

We wish to gain information on real, unique and variably developing courses (paths) of readership development, their causes and consequences for a person. Discovering the specifics of the creation of interest in reading can bring the possibilities of a more efficient formation of readership. The gained information can then be applied to the education of future and existing teachers of all teaching qualifications and education stages and future academics, since all of them can contribute to the development of students' skills for working with texts.

\section{Methodology}

The objective of this paper is to discover and describe the distinctions in the development of interest in reading (readership), as well as to deepen and update the available information on this process for students of the teaching profession and for teachers older by one generation.

Intermediate objectives:

1. Discover the specificity of the impact of factors on the readership of participants and the uniqueness of participants' individual reactions to them in various periods of ontogenetic and social development.

2. Compare the development of readership in student teachers in the 2 nd year of their studies with a group of second-year student teachers, but four years later. Simultaneously perform a generation comparison - this means to compare the outcomes of the students of the teaching profession with the characteristics of readership development in teachers older by one generation in order to discover the distinction of the impact of factors on readership at that time.

\footnotetext{
3 J. Trávníček in the publication Knihy a jejich lidé (Books and their People), Čtenářské životopisy (Reader Biographies), (2013) does not deduce any research conclusions from narratives.
} 


\section{Acta Educationis Generalis \\ volume 7, 2017, issue 3}

We ask a question: What specifics will we find in the way in which students of the teaching profession and teachers older by one generation subjectively see the development of their interest in reading?

Research methods: We obtained the necessary information through reader biographies.

Readership unfolds in the course of time, it has the attributes of a process and therefore it can be captured with recounting. The reader biography appears to be an adequate method of research of its development, as a form of narrative method. The biography's advantages consist of its authenticity, depiction of specificity and uniqueness of the described phenomena (readership development), which cannot be reached by quantitative methods. The objective of a narrative is to describe life stories and life experiences, to explain the actions of a person under research. The narrative method ranks among the interpretative methods. It concerns the complexity of the analysis of a narrative and its structuring from various perspectives and hierarchical levels within the meaning of Geertz's "thick description" (Geertz, 2000). A researcher analyses and interprets a narrative. A participant mentions the milestones (key events, storylines) that have affected him/her and changed his/her behaviour (Bruner, 1991). When he/she describes his/her reactions to them, he/she directly or indirectly reveals his/her motivation to action and experiencing (Gavora, 2006). The researcher is interested in all of this and gains another perspective: specific, but real contents of knowledge that fill the gap in the knowledge received using qualitative methods. It allows the research of an issue (in our case it is readership - interest in reading) at its development (Miovský, 2006; Švaříček, 2011). The reader biography represents a suitable method to discover readership factors (see Graf \& Schön, 1993, as cited in Garbe, 2008). ${ }^{4}$

Characteristics of the research group: At the first stage of the research in 2012, the research sample was formed by BA students of the teaching profession for primary schools and secondary schools in the 2nd year of study at the Faculty of Education at the University of Hradec Králové (PdF UHK). In total, 34 students (29 women, 5 men) marked as A group - participated in it. At the second stage of the research in 2016, the group of participants consisted of 27 students (10 men and 17 women) - marked as B group. They study or studied various specializations. ${ }^{5}$ The $\mathrm{C}$ group consisted of practicing teachers taking part in supplementary pedagogical study program within lifelong learning at the Faculty of Education at the University of Hradec Králové (PdF UHK) at the time of research in 2016. This group consisted of 12 persons ( 5 men and 7 women), mostly older by one generation (the youngest person was 36 years old and the oldest person was 50 years old $)^{6}$. They completed their university studies both in natural scientific and humanities disciplines. We assume that our participants, owing to their age and education level, have the ability to self-reflect and to provide relevant information on the development of readership, specifically interest in reading.

\footnotetext{
${ }^{4}$ We did not monitor the popularity of literary genres corresponding to age periods and trends.

5 Most of them attended primary schools in the second half of the nineties of the 20th century. The so-called "Harry Potter mania" occurred during their school attendance. They attended secondary schools in the period when PISA international research of readers' literacy took place.

${ }^{6}$ School attendance took place for persons at the age of forty and older mainly in the eighties during the socialist era, when the so-called new conception of teaching was introduced. The syllabus was uniform and literary education in primary education meant contemporary literary education (using active participation of pupils, texts of contemporary authors were to be worked with). The extent to which these purposes were fulfilled was not the objective of our research.
} 


\section{Acta Educationis Generalis \\ volume 7, 2017, issue 3}

\section{Research procedure}

Data collection: Students of the teaching profession - participants in the A and B groups - were asked at the workshop of General Didactics to record the development of their interest in reading starting from their birth until today in written form, and to mention the factors influencing their readership. We monitored the continual development of their readership from childhood until adulthood through the narratives of the participants under the title "My way to reading and readership." Through interviews with the selected participants of the survey, we completed the data on the preschool period. Participants in the $\mathrm{C}$ group worked on their statements on the same topic in the form of homework.

Data processing was performed in this sequence: open coding was performed firstly and then it was followed by the categorization of codes. We created an analytical story (Rabušicová, 2012) from the generated information, which represents a very simplified model of the development of interest in reading. We compared individual stories and compiled five trajectories of the development of interest in reading with similar courses of interest and other common features. They corresponded to the categories we created and that defined the individual types of readers. In constructing these categories, we actually reconstructed the principles, which are the basis of consideration and experiences of our players (Doubek \& Levínská, 2016). We repeated this procedure also at the second stage of the research conducted after four years. We performed a comparison of the results from both stages and determined the identical and different moments.

\section{Results}

We generated topics from the analysis of the stories to be further presented. The results of the A and B groups will be mentioned collectively, since they evinced identical characteristics. We will point out sporadic distinctions. We will publish the results of our comparison of the A and B groups with the C group separately.

\subsection{Topics}

The statements of participants proved some generally valid features of readers during individual age periods, for example interest in stories during the preschool period (Tamášová \& Šulganová, 2016, p. 26) and a crisis of readership in primary and lower secondary education. At the same time, we revealed many new interesting connections and a lot of distinctions in the effect of factors and reactions to individual topics.

First memories - positive and negative emotions (1.)

The first memory is always important in narratives, since it indicates an important determinant of further development (Chrz, 2007). Most of our participants commented firstly on the preschool period, when their parents or grandparents read to them or told fairy tales before sleeping. These moments left positive feeligs in them and that is why they recall them after so many years.

"A long time before school attendance my sister and I would wait in our beds in the evenings looking forward to the moment when our mum would come to our room, take 


\section{Acta Educationis Generalis \\ volume 7, 2017, issue 3}

one of the beautiful books of fairy tales from our library and start reading another story..." $(\mathrm{J} / \mathrm{A})^{7}$

We assume that moments of affinity and sharing of experiences with close persons had a simultaneous effect on them. This meant the first contact and experiences with stories and literature through which the primary reader's initiation, which is so important for the reader's socialization, occurred (Garbe, 2008; Gavora, 2017). However, it turned out that the positive effect of these first enjoyments and experiences on further development of readership in our readers was confirmed only partly. This effect was not enough in some participants to ensure a permanent motivation and a positive relationship to reading.

The emotions associated with the first memory were not always positive. Those who mentioned their first memory from as late as learning at primary school, always associated it with the displeasure of reading. They answered yes to the question whether their parents read them bed-time stories. However, these memories were obviously drowned out by the negative emotions evoked by the difficulties with reading in the first classes at primary school. They disrupted their desire to read, however, the time periods varied with different participants.

\section{Social factors in favour of readership (2.)}

The statements of participants proved that the social factors played the most important role on their way towards readership. That is why they were most often mentioned in narratives. They mentioned firstly their parents (very often also grandparents), teachers at school age and their same-age peers while growing up in chronological order. Other persons, for example librarians, affected them sporadically, nevertheless significantly. All of them played the role of the initiators of the readers' activities, represented a pattern for children and played an important role of supporting factors during the period of difficulties and in the process of decision-making in crisis situations. They formed the so-called supporting and communication contexts (Garbe, 2008; Rossenblatt, 1987, as cited in Bell \& McCallum, 2008; Beers, 2003; Short, 1997), however with diverse frequency and extent. We found an interesting circumstance. Readers showing a permanent high interest in reading most often mentioned the effect of family on the deepening of their interest in reading during childhood and the influence of teachers at school age. It is interesting that they did not mention their peers. On the contrary, sameage peers provided support to persons who did not like reading, or had reading difficulties up to lower secondary school. Thanks to them, their readership was supported and further developed. We can find the explanation in their need for belonging with their same-age peers, but also in the theory of cognitive consonance - they needed to share the same topics (in our case it was books and reading) and in this manner, they confirmed their attitudes (self-confirming).

Some participants needed these stimuli for several times at various periods of their lives (as late as at secondary school) from other persons, too. They maintained their interest in reading.

\footnotetext{
${ }^{7}$ Note: The first letter in bracket means the first letter in the participant's name, the second letter marks the participant's group.
} 


\section{Acta Educationis Generalis \\ volume 7, 2017, issue 3}

\section{Inner factors (3.)}

Inner factors evince quite naturally an important role. In particular, motivation forms a basis for readers' activities, for positive expectations from reading and attitudes. We identified a number of kinds of motivation for reading books. The cognitive motivation for the satisfaction of the need for learning in various areas of life, in the areas of professional interest or hobbies, was concerned for some participants. Emotional motivation was concerned for other participants - they were searching for reading material to induce enjoyment associated with fantasy and imagination. Many of them were motivated to read for relaxation and rest, or possibly to escape from the reality. Often, several sources of motivation occurred at the same time. They evinced social motivation (they read to have the opportunity to talk about a book with their friends) or performance motivation (they wanted to succeed at the secondary school leaving examination) sporadically.

“...At secondary school, I started to recognize that diving will not support me... and that I will need to do something with myself. I ended all sport activities, started to learn and started to read gradually. I never read more than I had to for my secondary school leaving examination or for some papers, but after all I made some progress." (K/A)

We recorded performance motivation or motivation with a social subtext in readers who started their way towards readership later. It was arisen by their teachers or same-age peers.

On the contrary, a loss of interest in reading was caused by difficulties with reading and "compulsory" literature (we will discuss this further below) for a small portion of participants in the first classes at primary school. The interest in sports or computers prevailed for some participants during pubescence. Their negative effect on readership, however, was not massive in our group. Most of our participants, students of grammar school, probably spent their leisure time by various activities of interest and by preparation for school.

The permanency and the depth of the interest affected the dynamics of readership and differentiated between groups of individuals. We identified a range of characteristics of interest as for the origin/expiry and lasting of interest: permanent interest during the entire developmental period, later on gained interest (permanently), gained several times, gradually lost interest and non-created interest. The depth of the interest also corresponds with its permanency. The features of interest are not uniformly represented among individuals. A deep interest was created based on the experiences with reading in a stimulating family environment. It is typical for readers with cognitive, emotional and esthetical motivation for reading.

Reader's crisis and turns - dynamics of development (4.)

A changing interest in reading appeared during certain crisis periods or turning points. They were developing a positive or a negative position. Readers' crises, unlike turns, had long-term existence (transition to another interest - to sport) and meant a gradual loss of interest in reading associated temporarily with forced reading. The first reader's crisis associated with difficulties in reading at primary school ended up differently. Only a negligible number of participants were beaten by it. The second reader's crisis at pubescence did not affect those for whom we monitored a permanent interest in reading. A negative attitude towards reading in other individuals at primary school was overcome 


\section{Acta Educationis Generalis \\ volume 7, 2017, issue 3}

at lower secondary school. On the contrary, the beginnings of readership appear to be positive in others, but they did not overcome a crisis of readership in pubescence.

The turning points were associated with a positive change. They took place quickly and were very varied - formed by a certain book (most often Harry Potter) ${ }^{8}$, events (a book given as a gift from a friend) or certain situations (when mum laughed while reading a certain book or when a friend kept talking about the same book). The decision-making processes were applied mainly by readers gained for reading several times at these turning points.

Perception of reading - "compulsory" reading is the biggest disaster (5.)

Participants distinguish in their stories between reading materials they like and read voluntarily and the so-called "compulsory" reading materials which are selected by teachers or recommended in pedagogical documents. All participants, regardless of their interest in reading, commented on it. The experiences and attitudes of the participants towards reading varied, they can be expressed on the scale: they hate it (it discourages) they consider it "necessary evil" - it does not bother them - they like it. The relationship to reading is changing over time. They re-evaluate their relationship to it and recognize its significance. Men, even if enthusiastic readers, are rather ironic in its evaluation.

"I developed my reading abilities better at primary school, and before I realized it, the first disaster came. This disaster, officially called "compulsory reading", was to my infinite sadness practised at all schools... only a look at that list of books induced my feeling of the "Grandma" book slightly." (O/A)

Perception of reading, interest in it and the attitudes towards it depend on the level of emotionality. Positive experiences induce an esthetical enjoyment, deepen one's interest in reading and strengthen the attitudes towards reading. ${ }^{9}$

\section{Evaluation of reading and readership, in him/herself and in others (6.)}

The quality of readership (permanence and depth of readers' interests, attitudes towards reading, experiences) is reflected in the orientation of evaluation (what is evaluated) and in the manner (how it is evaluated). The type of evaluation indicates the individuals' self-conception, self-efficacy and his/her level of independence/dependence. Some of them comment on the significance of reading in general and evaluate themselves at the same time. Other readers evaluate only themselves or pay attention to other people and their readership. They are distinguished also by the manner in which they currently evaluate reading, how significant it is for them and whether they have internalized the need for reading. The found variants of the concepts containing evaluation are as follows:

1. Reading is a matter of course for participants, it is highly appreciated, and they cannot imagine their life without reading. They read more and more demanding literature. Positive attitudes evince maturity and independence in fulfilling the requirements of institutions.

\footnotetext{
${ }^{8}$ In most cases, children like reading currently published popular titles.

9 If recommended reading does not satisfy the readers' preferences of pupils, the conception of literary education does not reflect their individual needs; situations when a book does not speak strongly to readers occur. If the reader is not satisfied in terms of the content or the aspect, the expectations regarding the content and the emotional level are not satisfied and the child reader does not experience esthetical enjoyments (Chaloupka, 1982).
} 


\section{Acta Educationis Generalis \\ volume 7, 2017, issue 3}

2. Reading is evaluated positively, the attitude towards reading is currently positive.

3. Reading was not always their inner need. Their opinion on reading is influenced by institutions (school, media); they would like to satisfy them.

4. They comment on the significance of reading in the sense that "I know I should do it, but I am not convinced about it". They cast doubt upon the influence of reading on their development (they probably know that they do not satisfy the requirements imposed by the society.).

5. Reading was had not been internalized by the members of this group, they do not have any need to read. They "resisted" the pressure exerted by institutions. They are actually independent. They do not comment on the significance of reading.

Modality "I would" relates to interest in reading, self-conception and relation to requirements imposed by institutions (7).

Variants of modality "I want - I can - I would like - I should - I do not want" often occur in narratives. Important information and connections can be learnt by reading them (Chrz, 2007). In our case, it is an indicator of the depth of interest in reading, selfconception and the attitude towards the requirements imposed by institutions. The forms "I want" and "I can" are a sign of high self-efficacy (Alverman, $2001^{10}$, as cited in Vacca et al, 2011, p. 169; Wiegerová et al, 2012; Bell, S., M. \& McCallum, R., S. et al., 2008). In this case, the participants regret that they do not have more time for reading a lot, however, they always make time for reading, which represents their inner need for this activity and habit. Modality "I would like" relates to the past and future. Relevant participants recognize lost opportunities. They make time for reading, when they have suitable conditions for it. The form "I should" depicts knowing that "I should read, but I have no time for reading," similarly to the case of the form "I do not want." They do not like changes, they are satisfied with the current state. These manifestations are completed also by the degree of independence/dependence on institutions, e.g. the requirements imposed by the school and also by the family.

Development line of interest in reading (8.)

The line of interest in reading differs with the intensity of interest and its position within the positive or negative zone during development. We could identify the following tendencies: 1. direct line of interest on the positive level, 2. ascending line, 3. variable line with the fluctuation of interest, 4 . descending line and 5. direct line, however on negative level. For illustration, it is graphically displayed in Fig. 1.

\footnotetext{
${ }^{10}$ Self-efficacy contributes to the reader's (literacy) identity of pupils (Alverman, 2001, as cited in Vacca et al, 2011, p. 169).
} 


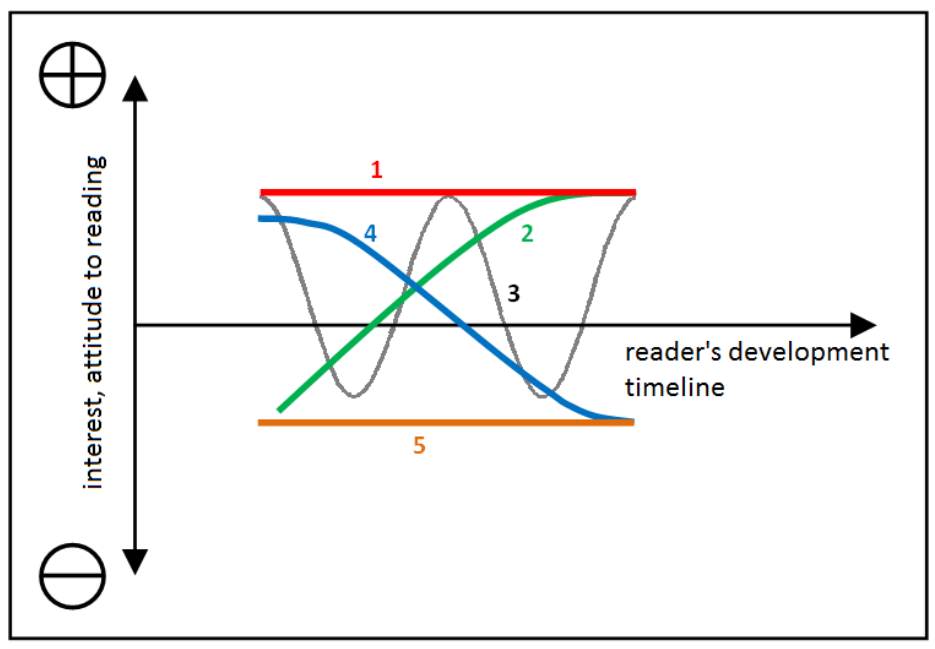

Figure 1. Development line of interest in reading.

Clue: The numbers of individual lines correspond to the types of lines (trajectories) of interest development.

4.2 The differences between the data obtained from the participants at the same stage of the teaching profession preparation and in the time interval of four years, and the differences in the comparison between generations.

The results of students of the teaching profession in the A and B groups did not change significantly. Only the B group prefers film adaptations of books and some of them needed a longer time period to internalize reading. Contemporary factors - computers are also recorded, however for the time being not to such a high extent.

Stories of readership development in teachers and individuals older by one generation (C group) differ one from another in some attributes. They rather emphasize the conditions of the home environment at childhood (libraries at their home, their parents read a lot and visited libraries). They do not allude so much to particular factors, crises or events during childhood or growing up. They do not mention "compulsory" reading or the secondary school leaving examinations at all. Currently, they recognize, when they play their new life roles and professional roles, the significance of readership for the development of their own children and pupils. They comment much more on the significance of reading and readership and highly appreciate its benefits for the development of children's and young people' personalities. They not only re-evaluate their relationship to reading, but also change their reader's behaviour in favour of the development of readership in children and pupils. They read books to their children, even if they themselves have not been big readers. Due to the effect of the experiences from childhood and of said attitudes, they copy their parents, who paid attention to them in this regard, represented role models for them and supported them in reading. Thereby they ensure the so-called generational transmission and continuity.

So, the concept of reading and readership in $\mathrm{C}$ group differs mainly regarding the attitudes to reading, their evaluation and reading behaviour, which they transformed into 


\section{Acta Educationis Generalis \\ volume 7, 2017, issue 3}

a positive level due to their experiences from childhood. These manifestations prove that readership is a long-term and dynamic phenomenon that can change over the entire life period due to the effects of various events and changes in life.

\subsection{Analytical story - a model of development of interest in reading that integrates topics extracted from the collected data}

Almost all participants underwent primary initiation in their family. Depending on the social stimuli from the environment, a higher or smaller interest in books and reading was established. Further, their interest was developing in various directions. If it persisted from childhood until today, it was associated with cognitive, emotional and esthetical motivation. However, if there were difficulties with reading in the first class of primary school, the participants lost their interest in reading at that time. It was renewed in some of them at the end of primary school and persisted also in the next period. If the interest in reading was raised as late as at lower secondary school, it was thanks to sameage peers. Reading allowed them to get into contact with friends who liked talking about books. The teachers managed, for a part of the participants (non-readers at that time), to initiate interest in reading as late as at secondary school. It means that, in some students, it is possible to initiate the interest in reading again. Some participants needed to have their interest encouraged repeatedly. However, a certain group did not succeed in returning to readership. The interest that they manifested at primary school was gradually lost at lower secondary school due to other hobbies. An interest in reading was not developed at all in several cases.

\subsection{Trajectory of readership development}

The construction of five types of trajectories was performed based on the narratives of the participants - stories reflecting the development of interest in reading. They were profiled by the distinctions in the above-mentioned topics. Each trajectory has similarly variable dynamics of development of interest in reading, but also of the reading activity, enjoyment, attitudes to reading, orientation and manner of evaluation associated with reading. They differ also with regard to self-conception.

\subsection{Typology of readers}

Trajectories are presented in newly established categories naming various types of readers: 1. eager reader, 2. gained reader (in A group), lukewarm reader (in B group), 3. reader from compulsion, 4. holiday reader and 5. "non-reader."

When presenting the individual types of readers, the characteristics of the A basic group will be mentioned, because they correspond to the manifestations of the B group. We have already pointed out some small differences.

1. Eager reader. From the beginning, they were internally motivated to read. Their interest in reading is permanent and deep. Reading satisfies them, brings pleasant experiences, and it stimulates their fantasy and desire for knowledge. They received many stimuli for reading from their family (see Tamášová \& Sulganová, 2016). Their readership was created naturally. They have a distinctive interest in a certain type of literature and collect a certain type of books. They read demanding literature already at an early age, which is more demanding compared to their same-age peers. That is why they are obviously not that bothered by compulsory reading. Apart from "compulsory" reading, they also manage to read "their own" 


\section{Acta Educationis Generalis \\ volume 7, 2017, issue 3}

favourite literature. They read it during more demanding periods, too. They highly appreciate reading. The interesting fact is that they do not comment on their sameage peers at all, unlike other readers.

The stories of the readers in this group are described with a detached view and they express attitudes towards reading and books. They are stuffed in terms of content and emotions, full of interesting topics, ideas and rich contexts. The trajectory of the development of interest in reading is displayed in Fig. 1/trajectory No. 1.

2. Gained reader. These readers' interest in reading started developing as late as at lower secondary school or maybe at upper secondary school. More impulses in sequence brought them to readership. They read a certain type of books and they still have a distaste for "compulsory" reading.

"I was not very much enthusiastic about reading, also due to compulsory reading, which, at the beginning, consisted mostly of titles like "Lovci mamutì" (Mammoth Hunters) and "Staré pověsti české" (Ancient Bohemian Legends). The forefather Čech or Veverčák with Kopčem (the characters from these titles) did not fascinate me to the extent which woudl change my attitude and become a passionate reader." (D/A)

Readers in this and the following trajectory think about themselves and evaluate their development. They reflect not only on the rigmarole of the development of readership, but also the manner in which they took hold of their readers' identities. They obviously have low self-efficacy and that is why they also comment on other readers and evaluate their reading habits. We can consider it an ideal strategy by means of which they delimit themselves negatively or positively towards other nonreaders (readers) in order to strengthen their own reader's identity. The trajectory of interest of readers in this group is displayed in Fig. 1/trajectory No. 2.

3. Compulsory reader. Their first memories are positive, because their parents or grandparents read them bed-time stories. Further, the storyline is very "zigzag," with periods of high interest changing into a disinterest in reading. They read at primary school from compulsion. At lower secondary school, they started reading books recommended by their schoolmates voluntarily in order to have a chance to discuss the books with their classmates.

5 They had a negative attitude towards compulsory reading. Nevertheless, they reevaluated it. They were motivated by a teacher of literature, or their inner performance motivation prevailed at secondary school - the desire to succeed at the secondary school leaving examinations. Some participants in this group admit that they will never be passionate readers. Their development of readership is displayed in Fig. 1/trajectory No. 3.

4. Holiday reader. Their story begins at preschool age with narration and reading of books by their parents or grandparents. Repeated reading of the same book at primary school and "holiday" reading in lower secondary school have become a specific phenomenon. An interest in reading became evident exceptionally in some students of this group at upper secondary school, however it gradually changed to the current disinterest. Their interest was distracted by computers, interest in sports or meeting friends. They actually became "non-readers" due to a lack of time. They have a strongly resistant attitude towards "compulsory" reading. Their trajectory is displayed in Fig. 1/trajectory No. 4. 


\section{Acta Educationis Generalis \\ volume 7, 2017, issue 3}

5. "Non-reader." The trajectory of this group is simple and without plotlines. The storyline is straight and within the range of disinterest. The participants do not mention the preschool period, they never liked reading. They have not read much, they read magazines occasionally. Utilitarian reading of informative texts of a nonartistic nature is rather concerned. Their story can be very briefly expressed. They mention only the actual state of their disinterest in reading. They evaluate practicably their state, do not pretend anything and they are not bothered that they do not read books. The trajectory of their development of interest is displayed in Fig. 1/trajectory No. 5 .

More detailed and well-arranged information on individual categories of readers are given in Table 1.

Table 1

Features of reader typologies and their characteristics

\begin{tabular}{|c|c|c|c|c|c|}
\hline \multirow[t]{2}{*}{ Features } & \multicolumn{5}{|c|}{ Typology of readers } \\
\hline & $\underline{\text { Eager reader }}$ & $\underline{\text { Gained reader }}$ & $\begin{array}{l}\text { Reader from } \\
\text { compulsion }\end{array}$ & $\underline{\text { Holiday reader }}$ & $\underline{\text { Non-reader }}$ \\
\hline $\begin{array}{l}\text { First } \\
\text { memory }\end{array}$ & Positive & Negative & Positive & Positive & $\begin{array}{l}\text { They do not } \\
\text { mention }\end{array}$ \\
\hline $\begin{array}{l}\text { External } \\
\text { factors }\end{array}$ & $\begin{array}{l}\text { Family, } \\
\text { teacher at the } \\
\text { secondary school }\end{array}$ & $\begin{array}{l}\text { Family, } \\
\text { same-age peers; } \\
\text { book }\end{array}$ & $\begin{array}{l}\text { Classmates, } \\
\text { teachers of } \\
\text { literature at the } \\
\text { secondary school }\end{array}$ & They do not state & $\begin{array}{l}\text { They do not } \\
\text { mention }\end{array}$ \\
\hline Motivation & $\begin{array}{l}\text { Cognitive, emo- } \\
\text { tional, esthetical }\end{array}$ & $\begin{array}{l}\text { Social, } \\
\text { emotional }\end{array}$ & Performance & $\begin{array}{l}\text { Emotional at the } \\
\text { beginning, now } \\
\text { without motiva- } \\
\text { tion }\end{array}$ & Non-motivated \\
\hline \multirow[t]{2}{*}{ Interest } & $\begin{array}{l}\text { Permanent and } \\
\text { deep interest }\end{array}$ & $\begin{array}{l}\text { Interest since } \\
\text { lower secondary } \\
\text { school, or } \\
\text { possibly as late } \\
\text { as at upper } \\
\text { secondary school }\end{array}$ & $\begin{array}{l}\text { Changing of } \\
\text { interest with } \\
\text { disinterest }\end{array}$ & $\begin{array}{l}\text { Interest only } \\
\text { during holidays }\end{array}$ & Was not created \\
\hline & Trajectory No. 1. & Trajectory No. 2. & Trajectory No. 3. & Trajectory No. 4. & Trajectory No. 5. \\
\hline $\begin{array}{l}\text { Reader's } \\
\text { crisis } \\
\text { and turns }\end{array}$ & None occurred & $\begin{array}{l}\text { Difficulties with } \\
\text { reading in pri- } \\
\text { mary school, } \\
\text { external factor as } \\
\text { a turn }\end{array}$ & $\begin{array}{l}\text { More crises } \\
\text { during childhood }\end{array}$ & $\begin{array}{l}\text { Other interests } \\
\text { since lower } \\
\text { secondary school }\end{array}$ & $\begin{array}{l}\text { Not mentioned } \\
\text { (permanent } \\
\text { disinterest) }\end{array}$ \\
\hline $\begin{array}{l}\text { Experience } \\
\text { of reading }\end{array}$ & $\begin{array}{l}\text { It satisfies them, } \\
\text { associated with } \\
\text { strong emotions }\end{array}$ & $\begin{array}{l}\text { Negative emo- } \\
\text { tions at the be- } \\
\text { ginning, now } \\
\text { positive enjoy- } \\
\text { ment }\end{array}$ & $\begin{array}{l}\text { Changing of } \\
\text { emotions accord- } \\
\text { ing to time peri- } \\
\text { od of disinterest } \\
\text { or interest }\end{array}$ & $\begin{array}{l}\text { Positive enjoy- } \\
\text { ments during } \\
\text { holiday reading }\end{array}$ & $\begin{array}{l}\text { Without } \\
\text { enjoyment }\end{array}$ \\
\hline
\end{tabular}




\section{Acta Educationis Generalis \\ volume 7, 2017, issue 3}

\begin{tabular}{|c|c|c|c|c|c|}
\hline Evaluation & $\begin{array}{l}\text { They highly } \\
\text { evaluate the sig- } \\
\text { nificance of } \\
\text { reading in gen- } \\
\text { eral and for } \\
\text { themselves }\end{array}$ & $\begin{array}{l}\text { They evaluate } \\
\text { their own devel- } \\
\text { opment and the } \\
\text { reading of others }\end{array}$ & $\begin{array}{l}\text { They evaluate } \\
\text { only their own } \\
\text { development }\end{array}$ & $\begin{array}{l}\text { They cast doubts } \\
\text { upon the signifi- } \\
\text { cance of reading. } \\
\text { They do not } \\
\text { evaluate them- } \\
\text { selves, but ex- } \\
\text { plain why the } \\
\text { others do not } \\
\text { read and why } \\
\text { people in general } \\
\text { do not read } \\
\text { much }\end{array}$ & $\begin{array}{l}\text { They evaluate } \\
\text { only themselves, } \\
\text { specifically } \\
\text { realistically }\end{array}$ \\
\hline $\begin{array}{l}\text { Self- } \\
\text { conception }\end{array}$ & $\begin{array}{l}\text { They do not con- } \\
\text { sider themselves } \\
\text { to be big readers. }\end{array}$ & $\begin{array}{l}\text { They are self- } \\
\text { assured to be fully- } \\
\text { fledged readers. }\end{array}$ & $\begin{array}{l}\text { They say they } \\
\text { are not passion- } \\
\text { ate readers. }\end{array}$ & $\begin{array}{l}\text { Reader only } \\
\text { during holidays }\end{array}$ & Non-reader \\
\hline & I want, I can & I want, I can & I would like & I should & I do not want \\
\hline $\begin{array}{l}\text { Modality "I } \\
\text { would" }\end{array}$ & $\begin{array}{l}\text { Independent of } \\
\text { requirements } \\
\text { from institutions. }\end{array}$ & $\begin{array}{l}\text { Partly independ- } \\
\text { ent of require- } \\
\text { ments from insti- } \\
\text { tutions. }\end{array}$ & $\begin{array}{l}\text { Effort to comply } \\
\text { with require- } \\
\text { ments from insti- } \\
\text { tutions }\end{array}$ & $\begin{array}{l}\text { Partly independ- } \\
\text { ent of require- } \\
\text { ments from insti- } \\
\text { tutions. }\end{array}$ & $\begin{array}{l}\text { Independent of } \\
\text { requirements } \\
\text { from institutions. }\end{array}$ \\
\hline $\begin{array}{l}\text { Making } \\
\text { time for } \\
\text { reading }\end{array}$ & $\begin{array}{l}\text { They always } \\
\text { make time }\end{array}$ & They make time & They make time & $\begin{array}{l}\text { They do not } \\
\text { make time, do } \\
\text { not have time }\end{array}$ & $\begin{array}{l}\text { They do not } \\
\text { make time, they } \\
\text { do not like it }\end{array}$ \\
\hline
\end{tabular}

\section{Discussion}

We can encounter various conceptions and typologies of readers in literature. The reader can be seen as an active and creative individual, who is interested in the world of literature and is a mental user of books. He/she keeps reader's books and discusses books he has read (Lepilová, 2014). Readers are characterized in this manner only in our first type of eager reader, however we identify as readers also those who are not devoted to reading and other activities associated with reading so intensively.

The commonly used category of non-readers was mentioned only in our eager readers and non-readers. Other types are distinguished from one another by periods when they read or read with dislike. We cannot say that our non-readers did not read at all, however they do not devote time to reading books.

Our classification of readers is not as complex as, for example, Graf's typology (Graf, 1995, as cited in Garbe, 2008, p. 13). ${ }^{11}$ In our typology, only from the aspect of motivation and interest, we can identify Graf"s first type of "conceptual" reader in our category "reader from compulsion" and his "esthetical" reader who corresponds to our

\footnotetext{
$11 \mathrm{~W}$. Graf determined types of readers based on readers' motivation and competences in the area of literary reception in adolescents and adult readers. He set aside a "conceptual reader," who did not read for pleasure, but his/her reading was based on the requirements and standards imposed by school. The type of "emotional reader" is the opposite, with whom children's pleasure from reading persists, however his/her readers' competences stagnate. Classic literature remains inaccessible for him. The third type is the "esthetical reader," who transformed pleasure from reading into esthetical pleasure, and identification competences were replaced with more dissociated competences, however internally engaged receptions (Graf, 1995, as cited in Garbe, 2008, p.13).
} 


\section{Acta Educationis Generalis \\ volume 7, 2017, issue 3}

type of "eager reader". Due to the distinction in criteria, Graf's other types of readers are mixed in our models and cannot be documented credibly.

\section{Conclusion}

Based on the subjective reflection of participants, we gained a partial insight into the specifics if the development of readership, and this was our objective. The factors were of various strength and permanence of the effect on motivation, interest, reader behaviour and attitudes of the participants. On this basis, we generated five types of trajectories and a relevant typology of readers that confirm the dynamics of the processes and their variety.

The results might be affected by the fact that they were gained as the memories of adults, who formed a small specific group of university students of the teaching profession and practicing teachers, future academics, where women predominated. Nevertheless, we believe that we revealed some interesting and serious facts (for example, the experiences with reading during childhood are important for a child in terms of the transmission between generations and continuity); and definitely also some unexpected results (young people can be gained for readership also at a later period of life; readership is subjected to lifelong changes). They update the content of the solved issues under changing life conditions and also from the ontogenetic point of view, and indicate topics which must be focused on in terms of the theoretical aspects as well as at the application level.

This issue requires the integration of various fields and interdisciplinary cooperation. Thus, the theory of readership, professional didactics and psychodidactics could be enriched.

\section{References}

Beers, K. (2003). When Kids Can't Read. What teachers can do. Portsmouth, NH: Heinemann

Bell, S., M., \& McCallum, R., S. et al. (2008). Handbook of Reading Assessment. Boston, MA: Pearson Allyn \& Bacon.

Bruner, J. (1991). Narrative construction of reality. Critical Inquiry, 18(1), 1-21.

Doubek, D., \& Levínská, M. (2016). Př́iběh jednoho neuskutečněného projektu: Pokus o vícehlasou narativní rekonstrukci politického konfliktu. Biograf, 118, 63-64. Retrieved from http://www.biograf.org/clanek.html?clanek=v6301

Garbe, Ch. (2008). Čtení v Německu: aktuální výsledky výzkumu, stav problematiky a koncepty podpory čtenářství. In Čtenářství, jeho význam a podpora. Praha: Skip, 519.

Gavora, P. (2017). Preschool Children in Book-Reading Situations with Parents: The Perspective of Personal Agency Theory. Studia paedagogica, 21(4), 99-116.

Gavora, P. (2006). Sprievodca metodológiou kvalitatívneho výskumu. Bratislava: Regent. Geertz, C. (2000). Interpretace kultur. Vybrané eseje. Praha: Slon.

Homolová, K. (2008). Pedagogicko-didaktické a psychosociální aspekty pubescentního čtenárství. Ostrava: Ostravská univerzita.

Chaloupka, O. (1982). Rozvoj dětského čtenářství. Praha: Albatros.

Chrz, V. (2007). Možnosti narativního přistupu v psychologickém výzkumu. Praha: PsÚ AV ČR.

Lepilová, K. (2014). Cesty ke čtenářství. Vyprávějte s námi. Brno: Edika. 


\section{Acta Educationis Generalis \\ volume 7, 2017, issue 3}

Miovský, M. (2006). Kvalitativní př́stup a metody v psychologickém výzkumu. Praha: Grada.

Pazonyi, J., \& Bodonyi, E. (2013). Developing language literacy in the educational scene. Acta Technologica Dubnicae, 3(2), 36-47. doi: 10.1515/atd-2015-0017

Poslední, P. (2005). Četba ze sociologického hlediska. Češtinářr, (15)4, 105-111.

Rabušicová, M., Kamanová, L., \& Pevná, K. (2012). Mezigenerační učení: Učit se mezi sebou v rodině. Studia pedagogica, 17(1), 163-182.

Short, K. G. (1997). Literature as Way of Knowing. Los Angeles: The Galef Institute.

Švaříček, R. (2011). Zlomové události při vytváření profesní identity učitele. Pedagogika.SK, 2(4), 247-274. Retrieved from http://www.casopispedagogika.sk /rocnik-2/cislo-4/ svaricek-studie.pdf

Tamášová, V., \& Šulganová, Z. (2016). Promotion of Family Reading in the Context of Children's Early Reading Literacy Development. Acta Technologica Dubnicae, 6(2), 9-28. doi: 10.1515/atd-2016-0009

Trávníček, J. (2008). Čteme? Obyvatelé České republiky a jejich vztah ke knize. Brno: Host.

Trávníček, J. (ed.). (2013). Knihy a jejich lidé. Čtenářské životopisy. Brno: Host.

Vacca, R. T., Vacca, J. L., \& Mraz, M. E. (2011). Content Area Reading. Boston: Pearson Education.

Wiegerová, A. et al. (2012). Self-efficacy v edukačných súvislostiach. Bratislava: SPN. 